\title{
An Exploration Of The Impact Of Strategic International Human Resource Management On Firm Performance: The Case Of Foreign MNCs In China
}

Chanzi Bao, Robert Gordon University, UK

Farhad Analoui, University of Bradford, UK

\begin{abstract}
The intense competition arising from globalization not only demands MNCs to seek low cost, innovation, speed and adaptability, but also brings the need to manage their human resources globally and strategically so that it becomes a source of sustained competitive advantage. It has thus led to the evolution of strategic international human resource management (SIHRM) in the literature, which not only acknowledges the need of balancing global integration and local responsiveness, but also emphasises the importance of seeking strategic fit between HR policies and business strategy, in turn leading to a superior business performance. Although it has been widely accepted that HR policies make a direct and positive impact on firm performance, the researcher believes there appears to be limited research undertaken in the context of the developing world.
\end{abstract}

Hence this paper focus upon the case of China with reference to foreign MNCs' operations and the challenges faced from the dual pressure of balancing globalisation and localisation. Consequently, the researcher selected a case study approach with a triangulation data collection method. Specifically, a two-stage primary data collection process of questionnaires and semistructured interviews were undertaken in four selected subsidiaries of MNCs in China. Thereafter, a series of statistical process was conducted, i.e. frequency analysis, reliability analysis, correlation and regression tests along with the transcripts from the rich data set of interviews.

The finding of this research strengthened the mainstream literature where there is a direct and positive relationship between HR polices and firm performance. Furthermore, this research also reinforced a number of views from previous studies on the importance of aligning HR policies with business strategy to attain strategic integration and thus the achievement of firm performance.

However, in contrast to previous studies this research found the quality enhancement of products and service was the preferred and currently adopted business strategy amongst the studied foreign $M N C s$ Chinese subsidiaries, whereas the traditional view regards cost reduction as contributing to the competitive edge in China. Moreover, this research also discovered that although headquarters initially transferred their standardised HR policies and procedures to Chinese subsidiaries, they subsequently delegated authority to subsidiaries. Therefore, foreign MNCs are seeking to balance global standardisation and local adaptation, which is a relatively new development although it has been noted in the literature. Thus, MNCs reconcile control and adaptation rather than satisfying one at the expense of the other, whereby the trend is for Western $H R$ policies to be gradually accepted and internalised by the younger generation of the Chinese workforce. 
Furthermore, drawing from the findings of this research upon the theoretical principles of Harvard Model (Beer et al., 1984), Guess Model (Guess, 1997, 2000) and Choice Model (Analoui, 2007) in terms of the link between HRM policy choices, HRM outcomes and firm performance, this research made recommendations to foreign MNCs to consider the adaptation of a set of HR policies that can generate competitive advantages, enhance employee commitment, increase job satisfaction, which lead to an improvement of firm performance. In addition, this research suggested foreign MNCs not only need to continually recognise the important role of the HR department in the devolvement of HR functions to line managers with the provision of training and organisational assistance, but also need to acknowledge the role of senior managers in achieving vertical integration between HR policies and business strategy and their influence in HR polices. Finally, foreign MNCs are encouraged to engage the HR department in the strategic level of the organisational operations (i.e. strategic planning process), in addition to its involvement on the functional/operational level of activities to achieve the sustained competitive advantage in the contemporary business context of China.

Keywords: strategic international human resource management; firm performance; multinational companies; China

\section{INTRODUCTION}

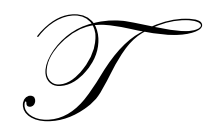

he intense competition arising from globalization not only demands low cost, innovation, speed and adaptability, but also brings the need to manage human resources strategically so that they become a source of sustained competitive advantage (Wright and McMahan, 1992; Boxall and Purcell, 2008). It has thus led to the evolution of strategic international human resource management (SIHRM) in the literature (Schuler et al., 1993; De Cieri and Dowling, 1999), which not only acknowledges the need of balancing global integration and local responsiveness (Evans et al., 2002), but also emphasises the importance of seeking strategic fit between HR policies and business strategy, in turn leading to a superior business performance (Bjorkman and Fan, 2002). There has been an increasing interest by management scholars in issues related to SIHRM over the last decade, particularly in relation to MNC performance. In particular, numerous empirical studies have indicated that HR policies positively and significantly affect firm performance (Jackson and Schuler, 1995; Richard and Johnson, 2001). However, there appear to be no studies focusing on senior management perception of the relationship between SIHRM effectiveness and firm performance in the context of China. Hence, there is a need and necessity, as well as scope and potential, to examine this aspect from the perception of senior managers (SMs) together with the influence from headquarters.

\section{LITERATURE REVIEW}

\section{The Concept Of SIHRM}

By combining the concept of SHRM with IHRM it identified a relatively new research area of SIHRM, which addressed the HRM issues and activities resulting from, and impacting on, the strategic activities and international concerns of MNCs as well as indicating the process of explicitly linking IHRM with their strategy (Schuler et al., 1993; Taylor et al., 1996). Therefore, SIHRM was defined as the "HRM issues, functions, policies and practices that result from the strategic activities of multinational enterprises and that impact the international concerns and goals of those enterprises" (Schuler et al., 1993: 720). Similarly, Taylor et al. (1996: 960) formulated that "SHRM [...], is used to explicitly link with the strategic management processes of the organisation and to emphasise coordination or congruence among various HRM practices. Thus, SIHRM is used explicitly to link IHRM with the strategy of the MNC". Therefore, the following literature was reviewed from two perspectives of SHRM and IHRM relating to MNCs. The former was developed to focus more upon the research of HR policies and firm performance and the strategic fit between HR policies and business strategies. Therefore, the subsequent sections involved the review of (i) firm performance and HRM and (ii) business strategies, HR policies and firm performance. Whilst the review of IHRM in this research emphasises two dilemmas faced foreign MNCs in China in terms of global integration/MNC standardization and/or local responsiveness/local adaptation. 


\section{Firm Performance And HRM}

Universalistic, contingency and configurational approaches in SHRM literature provide a theoretical foundation and developments of HR practices and firm performance relationship (Delery and Doty, 1996), the highlighted contribution of which have been reflected in the substantial number of empirical studies with an aim at examining the applied elements of theories and targeting the practitioners for management practice. Although it has been widely accepted that HR policies make a direct and positive impact on firm performance (i.e. Fombrun et al., 1984; Guest, 1999; Guthrie, 2001; Stavrou and Brewster, 2005; Purcell and Hutchinson, 2007; Dany et al., 2008), the researcher believes there appears to be limited research undertaken in the context of China. In addition to confirming that HRM activities directly influence the firm performance, a number of researchers (i.e. Fombrun $e t$ al., 1984; Guest, 1999, 2001; Paauwe, 2004) further explained that some HRM activities can give rise to HRM outcomes, which in turn influence firm performance.

\section{Business Strategies, HR Policies And Firm Performance}

This research adopted the classification of business strategies (i.e. cost-reduction, innovation and qualityenhancement) as proposed by Schuler and Jackson (1987). Literature indicated that a low-cost-oriented strategy was more likely to lead to short-term employment and lower education level in the workforce (Li, 2003). Indeed, firms with a low-cost strategy and HR practice had poorer performance than their counterparts with a more technologyintensive strategy (Li et al., 2000), whereas the innovation strategy affected HRM practices indicating the increasing dynamism of the Chinese economy in its move towards a market orientation (Ding and Akhtar, 2001), in particular, following China's entry into the WTO, foreign MNCs found it easier to compete in the Chinese market with their advanced technology (Cooke, 2008). Furthermore, several HRM models raised the importance of integrating HR policies with business strategy and emphasised the linkage with organisation performance, such as the Matching model (Fombrun et al., 1984), the Harvard model (Beer et al., 1984), the Guest model (Guest, 1999), the Storey model (Storey, 1989), the Warwick model (Hendry and Pettigrew, 1990) and the Choice model (Analoui, 2007). In addition, various researchers (i.e. Schuler and Jackson, 1987; Bjorkman and Fan, 2002) concluded that HR practices must be combined with specific business strategies to enhance organisation performance. Nevertheless, Fey et al. (2000) obtained limited support for the relationship between efforts at aligning HRM practices with firm strategy and subsidiary performance.

\section{Globalisation And/Or Localisation}

MNCs in China faced two dilemmas, firstly, to balance the need of global integration and/or local responsiveness, and secondly, the dual pressure of the adoption of Western management techniques and the workforce resistance (Bjorkman and Lu, 2001; Legewie, 2002). Given the contradictory findings of previous studies (i.e. Rosenzweig and Nohria, 1994; Kidd et al., 2001; Bjorkman et al., 2008; Morris et al. 2009), it was deemed imperative to extend the literature by further investigating the global integration/MNC standardization and/or local responsiveness/local adaptation in these four companies with a particular reference to the extent to which whether HQs transferred HRM policies and practices to their Chinese counterparts.

\section{METHODOLOGY}

A combination of quantitative and qualitative multi-method (triangulation) approach through case studies was adopted. Specifically, a two-stage primary data collection process of questionnaires and semi-structured interviews was undertaken. In particular, the data was gathered from a sample consisting of four Chinese subsidiaries of MNCs. Access was gained from the researchers' previous research and the utilization of personal contacts. This approach was viewed as necessary in China, a country where personal contacts significantly facilitate company access (Easterby-Smith and Malina, 1999; Bjorkman and Fan, 2002). Overall 70 from 98 SMs were participated in the survey, resulting in the response rate of $71 \%$. From this sample, 17 participants were selected for interviews, thereby constituting $24 \%$ of the valid respondents. In terms of measurement, the dependent variable is the perceived financial outcomes of the firm performance, whereby respondents were asked to compare the performance of their companies with the industry average over the past three years (2005-2007) based on five performance indicators (i.e. average return on investment, average profit, profit growth, average return on sales and 
average market share growth) on a Likert-type scale ranging from 1 (well below) to 5 (well above). Further, scores for these five items were averaged into a single performance variable in order to simplify the process. Whereas, independent variables include HR policies and business strategies. Various Likert-style items were used to measure independent variables argued to reflect the underlying dimensions of the influential factors upon firm performance.

\section{DATA ANALYSIS}

\section{Relationship Between HR Policies And Firm Performance}

This relationship was examined firstly through frequency analysis, whereby the relative majority of SMs believed that HR policies are making direct $(43.5 \%$ in comparison with $24.6 \%$ of disagreement and $31.9 \%$ of unawareness) and positive impact (49.2\% in comparison with $21.7 \%$ of disagreement and $29 \%$ of unawareness) on firm performance, then examined through correlation and regression tests (see Tables 1-2). This finding strengthened the mainstream literature where there is a direct and positive relationship between HR polices and firm performance (i.e. Fombrun et al., 1984; Ngo et al., 1998; Guest, 1999; Chang and Chen, 2002; Stavrou and Brewster, 2005; Purcell and Hutchinson, 2007; Dany et al., 2008).

Furthermore, drawing upon the ideas derived from the variety of conceptual models examining the linkage between HR policies, HR outcomes and firm performance, this research sought to incorporate two mediating factors of employee commitment and job satisfaction as to reflect the HR outcomes in these conceptual models, then investigated the impact of HR policies on firm performance. Subsequently, frequency analysis showed that over $60 \%$ of SMs believed that firstly, the importance of developing a set of appropriate HR policies aiming at attaining HR outcomes and secondly, when HR outcomes were reached, the greater level of business performance can be expected. Moreover, this was also examined through correlation and regression tests (see Tables 1-2). This finding strengthened the theoretical models (i.e. Formbrun et al., 1984; Beer et al., 1984; Guest, 1999, 2001; Paauwe, 2004).

In addition, this relationship was examined through the frequency analysis of two statements, i.e. ' $H R$ policies are creating competitive advantages' and 'HR policies are directly influenced by SMs and their effectiveness at work', together with correlation and regression tests (see Tables 1-2). Over half of the SMs across all four companies believe that they have control over HR policies and thereafter, give rise to HR policies that in turn generate competitive advantage. This finding has confirmed the well-established views in the literature (i.e. Barney, 1991; Boxall, 1996, 1998; Boxall and Purcell, 2008), where it was reviewed from the perspective of human resource advantage, suggesting that a series of HR polices, practices and processes together contributed to the competitive advantage of the organisation. Indeed, as Huselid (1995) stated, a bundle of HR policies and practices jointly contributed to the attainment of the organisation's strategies by matching resources to organisational needs, improving performance and quality, and achieving competitive advantage.

Correlation results in Table 1 did not indicate any statistically significant association between the tested variables and firm performance. Subsequently, this was then further examined through regression (see Table 2) with the independent variables disaggregated into their constituent responses: 'strongly disagree', 'disagree', 'agree' and 'strongly agree'. Overall, a series of bundled factors is found statistically significant, indicating that it mainly agree/strong agree responses that are statistically significant, although there is some strong disagreement in relation to the omitted category of 'no opinion'/'don't know'. In other words, the HR policies that are characterised by the ability of creating competitive advantages, positively affecting employee commitment and job satisfaction and being recognised by senior management have a positive impact on firm performance. 
International Journal of Management \& Information Systems - Fourth Quarter 2011

Volume 15, Number 4

\begin{tabular}{|c|l|c|c|c|c|c|c|c|}
\hline \multicolumn{1}{|c|}{ Table 1: HR Policies: Mean, Standard Deviation And Correlation } \\
\hline
\end{tabular}

Where: $* *=p<0.01 ; *=p<0.05$

Source: data analysis

Table 2: Relationship Between HR Policies And Firm Performance: OLS Regression

\begin{tabular}{|c|c|c|c|c|c|c|}
\hline Variable & $\begin{array}{c}\text { HR policies are } \\
\text { creating competitive } \\
\text { advantages }\end{array}$ & $\begin{array}{c}\text { HR policies have a } \\
\text { direct impact on firm } \\
\text { performance }\end{array}$ & $\begin{array}{c}\text { HR policies have a } \\
\text { positive impact on firm } \\
\text { performance }\end{array}$ & $\begin{array}{c}\text { HR policies positively } \\
\text { affect employees' } \\
\text { commitment }\end{array}$ & $\begin{array}{c}\text { HR policies } \\
\text { positively affect } \\
\text { job satisfaction }\end{array}$ & $\begin{array}{c}\text { HR policies are } \\
\text { directly influenced } \\
\text { by senior managers }\end{array}$ \\
\hline \multirow[t]{2}{*}{ Constant } & $3.284 * * *$ & $3.400 * * *$ & $3.380 * * *$ & $3.318 * * *$ & $3.222 * * *$ & $3.233 * * *$ \\
\hline & $(22.773)$ & $(24.983)$ & $(23.242)$ & $(21.432)$ & $(21.411)$ & $(25.230)$ \\
\hline \multirow{2}{*}{$\begin{array}{l}\text { Strongly } \\
\text { disagree }\end{array}$} & $0.573^{* *}$ & 0.457 & 0.445 & $0.516^{*}$ & $0.611^{* *}$ & $0.700^{* *}$ \\
\hline & $(2.061)$ & $(1.650)$ & $(1.636)$ & $(1.701)$ & $(2.030)$ & $(2.443)$ \\
\hline \multirow[t]{2}{*}{ Disagree } & -0.034 & -0.120 & -0.180 & 0.182 & 0.338 & $0.767 * *$ \\
\hline & $(0.129)$ & $(0.493)$ & $(0.630)$ & $(0.514)$ & (1.046) & $(2.261)$ \\
\hline \multirow[t]{2}{*}{ Agree } & $0.674 * * *$ & $0.627 * * *$ & $0.509 * * *$ & 0.316 & $0.543 * * *$ & $0.671 * * *$ \\
\hline & (3.492) & (3.259) & $(2.652)$ & $(1.629)$ & $(2.836)$ & (3.663) \\
\hline \multirow{2}{*}{$\begin{array}{l}\text { Strongly } \\
\text { agree }\end{array}$} & $0.607 * *$ & 0.350 & $0.563 * *$ & $0.916^{* * *}$ & $0.887 * * *$ & $0.617 * * *$ \\
\hline & $(2.547)$ & $(1.328)$ & $(1.971)$ & $(3.805)$ & $(3.629)$ & $(2.778)$ \\
\hline $\mathrm{F}$ & $4.439 * * *$ & $3.822 * * *$ & $3.094 * *$ & $3.826^{* * *}$ & $3.811 * * *$ & $4.490 * * *$ \\
\hline $\mathrm{R}^{2}$ & 0.217 & 0.193 & 0.162 & 0.193 & 0.192 & 0.219 \\
\hline Adj. $R^{2}$ & 0.168 & 0.142 & 0.110 & 0.143 & 0.142 & 0.170 \\
\hline $\mathrm{n}$ & 69 & 69 & 69 & 69 & 69 & 69 \\
\hline
\end{tabular}

Dependent variable: Firm performance

Where: $* * *=p<0.01 ; * *=p<0.05 ; *=p<0.1$

Absolute t-ratios in parentheses

Source: data analysis 


\section{Business Strategies, HR Policies And Firm Performance}

In order to highlight the pursued business strategies in these four companies, respondents were asked to rate its importance in their target market. The subjective responses were firstly recorded on a Likert five-point scale (1=least important to $5=$ most important) from which a mean value was then calculated. Consequently, this revealed the following averages: 4.24 for the cost reduction, 4.66 for the quality enhancement and 4.53 for the innovation of products and services. Therefore, it can be concluded that the quality of products and services was the most important business strategy that all four companies were seeking followed by the innovation business strategy, whilst cost reduction appeared to be the least important business strategy amongst all four foreign MNCs' subsidiaries in China. Based on the existing literature, because of the difficulties to compete on low cost with SOEs and the avoidance of price wars ( $\mathrm{Li}$ et al., 2000), foreign businesses shifted their investment pattern from the traditional manufacturing sector featured by the cheap labour cost as competitive advantages towards the sectors characterized by high-tech and high value-added since the 1990s (Cooke, 2008). This was also in line with the developing trend in the Western countries, whereby the increasing pressure on innovation encouraged MNCs to transfer knowledge and learning in a coordinated way across different international operations. Following these changes and the increasing dynamism of the Chinese economy towards a market orientation, in particular with China's entry into the WTO, the low cost strategy was more likely to lead to short-term employment and lower education level in the workforce ( $\mathrm{Li}, 2003)$.

Relating to the degree of integration between business strategies and HR policies, the frequency analysis showed the relative majority of SMs (45.7\% in comparison with $18.6 \%$ of disagreement and $35.7 \%$ of unawareness) believed the achievement of this alignment between HR policies and business strategy in their companies. Indeed, this appeared to be particularly important given that a number of studies (e.g. Miles and Snow, 1984; Porter, 1985; Schuler and Jackson, 1987; Bjorkman and Fan, 2002) commented that HR practices must fit with specific business strategies to enhance organisational performance. Finally, the relationship between the alignment of HR policies with business strategy and firm performance was examined through correlation and regression tests (see Tables 3-4).

Table 3: Fitness Between HR Policies And Business Strategy: Mean, Standard Deviation And Correlation

\begin{tabular}{|c|l|c|c|c|}
\hline & \multicolumn{1}{|c|}{ Variable } & Mean & Standard deviation & $\mathbf{1}$ \\
\hline 1 & Firm performance & 3.67 & 0.69 & \\
\hline 2 & HR policies 'fit' with the business strategy & 0.46 & 0.50 & $0.35^{* *}$ \\
\hline
\end{tabular}

Where: $* *=p<0.01$

Source: data analysis

Table 4: Relationship Between Alignment Of HR Policies With Business Strategy And Firm Performance: OLS Regression

\begin{tabular}{|l|c|}
\hline \multicolumn{1}{|c|}{ Variable } & HR policies 'fit' with business strategy \\
\hline Constant & $3.453^{* * *}$ \\
\cline { 2 - 3 } & $(32.733)$ \\
\hline \multirow{2}{*}{ Yes } & $0.483^{* * * *}$ \\
\cline { 2 - 3 } & $(3.068)$ \\
\hline $\mathrm{F}$ & $9.415^{* * *}$ \\
\hline $\mathrm{R}^{2}$ & 0.123 \\
\hline Adj. $\mathrm{R}^{2}$ & 0.110 \\
\hline $\mathrm{n}$ & 69 \\
\hline
\end{tabular}

Dependent variable: Firm performance

Where: $* * *=p<0.01 ; * *=p<0.05 ; *=p<0.1$

Absolute t-ratios in parentheses

Source: data analysis

The positive statistically significant association demonstrated in Table 3 indicated that firm performance might be affected by the alignment of HR policies with business strategy. Hence, this was further tested through regression to examine the size of this association (see Table 4) with the independent variable disaggregated into its 
constituent responses of 'yes', 'no' and 'don't know'. Overall this was found statistically significant ( $\mathrm{F}=9.415, p<$ 0.01) explaining some 12 percent of the variation in firm performance. In relation to the individual responses to the question of the existence of the integration between HR policies and business strategy, then the selection of 'yes' was the only response being chosen and found statistically significant. Hence, it suggested that firm performance is influenced by the existence of the alignment between company HR policies with business strategy. This finding acknowledged the strong links between HR strategy and general business strategies as the model of Guest (1999) conceptualised. Moreover, this research also underpinned a number of existing opinions, such as Fombrun et al. (1984), Schuler and Jackson (1987), Chang and Chen (2002), Bjorkman et al. (2008), Dany et al. (2008).

In addition, the frequency analysis showed the relative majority of SMs (50\% in comparison with $11.4 \%$ of disagreement and $38.6 \%$ of unawareness) believed that they consider HR policies and procedures when adopting organisational strategy. This finding corresponded to the views of Analoui $(1999,2002,2007)$ and Bao (2009) who stressed the importance for SMs to recognise their role in the effectiveness of HR functions corresponding to business strategy, whilst the impact of these on firm performance was reflected in the results of the correlation and regression tests. Overall this was found statistically significant $(\mathrm{F}=6.375, p<0.01)$ explaining some 29 percent of the variation in firm performance. In relation to the individual responses to this issue, then the responses of 'strongly disagree', 'agree' and 'strongly agree' were found statistically significant. The former was a surprising result, but was only marginally significant, whilst the latter two were as expected and highly significant and clearly outweigh the former in their impact. Hence, this indicated SMs considered HR policies when adopting organisational strategy, which subsequently make positive impact upon firm performance.

\section{Globalisation And/Or Localisation}

This issue was explored from both survey and interviews via the question of "whether companies' HR policies were transferred from their HQs". The frequency analysis showed SMs in Companies A (100\%) and C (93.3\%) recognised that HR policies were transferred from their HQs, which confirmed the findings of Bjorkman and $\mathrm{Lu}$ (2001) and Morris et al. (2009), who proposed the successful implementation of global standardized HR practices in Chinese subsidiaries. However, the relative majority of SMs in Company B (56.3\% in comparison $43.8 \%$ of disagreement and none of agreement) showed unawareness. In contrast, there was equal distribution (42.9\%) between agreement and disagreement in Company D. Therefore, the further investigation was undertaken through interviews, which clarified these two companies blended global standardization with local responsiveness. This finding corresponded to the research of Taylor et al. (1996) and Cooke (2008), whereby MNCs not only faced the need of balancing global integration and local adaptation as entering the Chinese market through JVs with local firms, but also faced the challenge of the dual pressure from the adoption of Western management practices and the local workforce's resistance (Legewie, 2002). Indeed, MNCs reconciled control and adaptation rather than satisfying one at the expense of the other, whereby the trend was for Western HR policies to be gradually accepted and internalized by the younger generation of the Chinese workforce (Cooke, 2008).

\section{CONCLUSION}

The finding of this research strengthened the mainstream literature where there is a direct and positive relationship between HR polices and firm performance. Furthermore, this research also reinforced a number of views from previous studies on the importance of aligning HR policies with business strategy to attain strategic integration and thus the achievement of firm performance. However, in contrast to previous studies, this research found the quality enhancement of products and service was the preferred and currently adopted business strategy amongst the studied foreign MNCs Chinese subsidiaries, whereas the traditional view regards cost reduction as contributing to the competitive edge in China. Moreover, this research also discovered that although headquarters initially transferred their standardised HR policies and procedures to Chinese subsidiaries, they subsequently delegated authority to subsidiaries. Therefore, foreign MNCs are seeking to balance global standardisation and local adaptation, which is a relatively new development although it has been noted in the literature. Thus, MNCs reconcile control and adaptation rather than satisfying one at the expense of the other, whereby the trend is for Western HR policies to be gradually accepted and internalised by the younger generation of the Chinese workforce. 


\section{AUTHOR INFORMATION}

Dr Chanzi Bao is a Lecturer in Human Resource Management in the Department of Management within Aberdeen Business School at the Robert Gordon University. She graduated with a BA (Hons) in Public Administration from Heilongjiang University, China, a MA in International Business and Management and a PhD in Human Resource Management at the University of Bradford which included a placement at EM-Lyon University, France. Her research interests include Development of HR policies and practices in China, Managerial effectiveness in MNCs' Chinese subsidiaries, Cultural aspects of HRM, HRM effectiveness and firm performance, work-life balance and job satisfaction/labour turnover in China. E-mail: c.bao@rgu.ac.uk

Dr. Farhad Analoui is a Professor, International Development and Human Resource Management, University of Bradford. He lectures on managerial effectiveness, strategic human resource management, industrial sabotage, public sector reform and restructuring. He has carried out empirical research in the UK, Germany, Romania, Zimbabwe, Ghana, the Middle East, Iran, Croatia, Oman, Indonesia, and China, and supervises Masters and PhD projects. He has published several books, articles in international academic/professional journals and acts as a referee on the editorial boards of journals. Professor Analoui works as a management consultant and acts as consultant/advisor to British Council and DfID on management matters. E-mail: f.analoui@ bradford.ac.uk

\section{REFERENCES}

1. Analoui, F. (1999) Eight Parameters of Managerial Effectiveness: A Study of Senior Managers in Ghana, Journal of Management Development, 18 (4): 362-89.

2. Analoui, F. (2002) Politics of Strategic Human Resource Management: A 'Choice' Model, in F. Analoui (ed.) The Changing Patterns of Human Resource Management. Aldershot: Ashgate.

3. Analoui, F. (2007) Strategic Human Resource Management. London: Thomson.

4. Bao, C. (2009) Comparison of Public and Private Sector Managerial Effectiveness: A Three Parameter Approach, Journal of Management Development, 28 (6): 533-541.

5. Barney, J. (1991) Firm Resources and Sustained Competitive Advantage, Journal of Management, 17 (1): 99-120.

6. $\quad$ Beer, M., Spector, B., Lawrence, P.R., Quinn Mills, D. and Walton, R.E. (1984) Managing Human Assets. New York, NY: The Free Press.

7. Bjorkman, I. and Fan, X. (2002) Human Resource Management and the Performance of Western Firms in China, International Journal of Human Resource Management, 13 (6): 853-864.

8. Bjorkman, I. and Lu, Y. (2001) Institutionalisation and Bargaining Power Explanations of Human Resource Management in International Joint Ventures: The Case of Chinese-Western Joint Venture, Organization Studies, 22 (3): 491-512.

9. Bjorkman, I., Budhwar, P., Smale, A. and Sumelius, J. (2008) Human Resource Management in Foreignowned Subsidiaries: China versus India, The International Journal of Human Resource Management, 19 (5): 964-978.

10. Boxall, P. (1996) The Strategic HRM Debate and The Resource-based View of the Firm, Human Resource Management Journal, 6 (3): 59-75.

11. Boxall, P. (1998) Achieving Competitive Advantage through Human Resource Strategy: Towards a Theory of Industry Dynamic, Human Resource Management Review, 8 (3): 265-288.

12. Boxall, P. and Purcell, J. (2008) Strategy and Human Resource Management. Basingstoke: Palgrave Macmillan.

13. Chang, P.L. and Chen, W.L. (2002) The Effect of Human Resource Management Practices on Firm Performance: Empirical Evidence from High-tech Firms in Taiwan, International Journal of Management, 19 (4): 622-31.

14. Cooke, F.L. (2008) Competition, Strategy and Management in China. Basingstoke: Palgrave Macmillan.

15. Dany, F., Guedri, Z. and Hatt, F. (2008) New Insights into the Link between HRM Integration and Organizational Performance: The Moderating Role of Influence Distribution between HRM Specialists and Line Managers, International Journal of Human Resource Management, 19 (11): 2095-2112. 
16. De Cieri, H. and Dowling, P. (1999) Strategic Human Resource Management in Multinational Enterprises: Theoretical and Empirical Developments, in P. Wright, L. Dyer, J. Boudreau and G. Milkovich (eds.) Research in Personnel and Human Resource Management. Greenwich, CT: JAI Press.

17. Delery, J.E. and Doty, D.H. (1996) Modes of Theorizing in Strategic Human Resource Management: Tests of Universalistic, Contingency and Configurational Performance Predictions, Academy of Management Journal, 39 (4): 802-835.

18. Ding, D.Z. and Akhtar, S. (2001) The Organizational Choice of Human Resource Management Practices: A Study of Chinese Enterprises in Three Cities in the PRC, International Journal of Human Resource Management, 12 (6): 946-964.

19. Evans, P., Pucik, V. and Barsoux, J.L. (2002) The Global Challenge: Frameworks for International Human Resource Management. New York, NY: McGraw-Hill.

20. Fey, C., I. Bjorkman and A. Pavlovskaya (2000) The Effect of Human Resource Management Practices on Firm Performance in Russia. International Journal of Human Resource Management, 11 (1): 1-18.

21. Fombrun, C., Tichy, N.M. and Devanna, M.A. (1984) Strategic Human Resource Management. New York, NY: John Wiley and Sons.

22. Gratton, L. and Hope-Hailey, V. (1999) Linking Individual Performance to Business Strategy: The People Process Model, Human Resource Management, 38 (1): 17-31.

23. Guest, D.E. (1999) Human Resource Management: The Workers' Verdict, Human Resource Management Journal, 9 (2): 5-25.

24. Guest, D.E. (2001) Human Resource Management: When Reality Confronts Theory, International Journal of Human Resource Management, 12 (7): 1092-1106.

25. Guthrie, J.P. (2001) High-involvement Work Practices, Turnover and Productivity: Evidence from New Zealand, Academy of Management Journal, 44 (1): 180-190.

26. Hendry, C. and Pettigrew, A. (1990) Human Resource Management: An Agenda for the 1990s, International Journal of Human Resource Management, 1 (1): 17-44.

27. Huselid, M.A. (1995) The Impact of Human Resource Management on Turnover, Productivity and Corporate Financial Performance, Academy of Management Journal, 38 (3): 635-672.

28. Jackson, S.E. and Schuler, R.S. (1995) Understanding Human Resource Management in the Context of Organizations and their Environments, Annual Review of Psychology, 46: 237-264.

29. Kidd, J.B., Li, X. and Richter, F.J. (2001) Advances in Human Resource Management in Asia. Basingstoke: Palgrave.

30. Legewie, J. (2002) Control and Co-ordination of Japanese Subsidiaries in China: Problems of an Expatriate-Based Management System, International Journal of Human Resource Management, 13 (6): 901-919.

31. Li, J. (2003) Strategic Human Resource Management and MNEs' Performance in China, International Journal of Human Resource Management, 14 (2): 157-173.

32. Miles, R.E. and Snow, C.C. (1984) Designing Strategic Human Resource System, Organizational Dynamics, 13 (1): 36-52.

33. Morris, J., Wilkinson, B. and Gamble, J. (2009) Strategic International Human Resource Management or the 'Bottom Line'? The Cases of Electronics and Garments Commodity Chains in China, The International Journal of Human Resource Management, 20 (2): 348-371.

34. Ngo, H., Turban, D., Lau, C. and Lui, S. (1998) Human Resource Practices and Firm Performance of MNCs: Influence of Country of Origin, International Journal of Human Resource Management, 9 (4): 632652.

35. Paauwe, J. (2004) HRM and Performance: Achieving Long Term Viability. Oxford: Oxford University Press.

36. Porter, M.E. (1985) Competitive Advantage: Creating and Sustaining Superior Performance. New York, NY: The Free Press.

37. Purcell, J. and Hutchinson, S. (2007) Front-line Managers as Agents in the HRM-performance Causal Chain: Theory, Analysis and Evidence, Human Resource Management Journal, 17 (1): 3-20.

38. Richard, O.C. and Johnson, N.B. (2001) Strategic Human Resource Management Effectiveness and Firm Performance, International Journal of Human Resource Management, 12 (2): 299-310.

39. Rosenzweig, P.M. and Nohria, N. (1994) Influences on Human Resource Management Practices in Multinational Corporations, Journal of International Business Studies, 25 (2): 229-251. 
40. Schuler, R.S. and Jackson, S.E. (1987) Linking Competitive Strategies with Human Resource Management Practices, Academy of Management Executive, 1 (3): 207-219.

41. Schuler, R.S., Dowling, P.J. and De Cieri, H. (1993) An Integrative Framework of Strategic International Human Resource Management, International Journal of Human Resource Management, 4 (4): 717-764.

42. Stavrou, E.T. and Brewster, C. (2005) The Configurational Approach to Linking Strategic Human Resource Management Bundles with Business Performance: Myth or Reality? Management Revue, 16 (2): 186-202.

43. Storey, J. (1989) Introduction: from Personnel Management to Human Resource Management, in J. Storey (ed.) New Perspectives on Human Resource Management. London: Routledge.

44. Taylor, S., Beechler, S. and Napier, N. (1996) Toward an Integrative Model of Strategic International Human Resource Management, Academy of Management Review, 21 (4): 959-985.

45. Wright, P.M. and McMahan, G.C. (1992) Theoretical Perspectives for Strategic Human Resource Management, Journal of Management, 18 (2): 295-320. 